\title{
Size-fractionated dissolved primary production and carbohydrate composition of the coccolithophore Emiliania huxleyi
}

\author{
C. Borchard ${ }^{1,2}$ and A. Engel ${ }^{1,2}$ \\ ${ }^{1}$ GEOMAR - Helmholtz Centre for Ocean Research, 24105 Kiel, Germany \\ ${ }^{2}$ Alfred Wegener Institute for Polar and Marine Research, 27570 Bremerhaven, Germany \\ Correspondence to: A. Engel (aengel@geomar.de)
}

Received: 7 October 2014 - Published in Biogeosciences Discuss.: 4 November 2014

Revised: 14 January 2015 - Accepted: 25 January 2015 - Published: 27 February 2015

\begin{abstract}
Extracellular release (ER) by phytoplankton is the major source of fresh dissolved organic carbon (DOC) in marine ecosystems and accompanies primary production during all growth phases. Little is known, so far, on size and composition of released molecules, and to which extent ER occurs passively, by leakage, or actively, by exudation. Here, we report on ER by the widespread and bloomforming coccolithophore Emiliania huxleyi grown under steady-state conditions in phosphorus-controlled chemostats $\left(\mathrm{N}: \mathrm{P}=29\right.$, growth rate of $\left.\mu=0.2 \mathrm{~d}^{-1}\right)$ at present-day and high- $\mathrm{CO}_{2}$ concentrations. ${ }^{14} \mathrm{C}$ incubations were performed to determine primary production (PP), comprised of particulate $\left(\mathrm{PO}^{14} \mathrm{C}\right)$ and dissolved organic carbon $\left(\mathrm{DO}^{14} \mathrm{C}\right)$. Concentration and composition of particulate combined carbohydrates $(p \mathrm{CCHO})$ and high-molecular-weight $(>1 \mathrm{kDa}$, HMW) dissolved combined carbohydrates $(d \mathrm{CCHO})$ were determined by ion chromatography. Information on size distribution of ER products was obtained by investigating distinct size classes $\left(<0.4 \mu \mathrm{m}\left(\mathrm{DO}^{14} \mathrm{C}\right),<0.45 \mu \mathrm{m}(\mathrm{HMW}\right.$ $d \mathrm{CCHO}),<1000,<100$ and $<10 \mathrm{kDa})$ of $\mathrm{DO}^{14} \mathrm{C}$ and HMW- $d$ CCHO. Our results revealed relatively low ER during steady-state growth, corresponding to $\sim 4.5 \%$ of primary production, and similar ER rates for all size classes. Acidic sugars had a significant share on freshly produced $p \mathrm{CCHO}$ as well as on HMW- $d \mathrm{CCHO}$. While $p \mathrm{CCHO}$ and the smallest size fraction $(<10 \mathrm{kDa})$ of $\mathrm{HMW}-d \mathrm{CCHO}$ exhibited a similar sugar composition, dominated by high percentage of glucose (74-80 mol \%), the composition of HMW$d$ CCHO size classes $>10 \mathrm{kDa}$ was significantly different, with a higher mol $\%$ of arabinose. The mol $\%$ of acidic sugars increased and that of glucose decreased with increasing size of HMW- $d \mathrm{CCHO}$. We conclude that larger polysaccha-
\end{abstract}

rides follow different production and release pathways than smaller molecules, potentially serving distinct ecological and biogeochemical functions.

\section{Introduction}

The global ocean inventory of dissolved organic carbon (DOC) is estimated to be in the range of 662-700 Gt (Hansell and Carlson, 1998; Ogawa and Tanoue, 2003). A common classification of marine DOC relies on its reactivity and discriminates between labile (LDOC), semi-labile (SLDOC), semi-refractory (SRDOC), refractory (RDOC) and ultrarefractory (URDOC) DOC with lifetimes of hours to days, weeks to months, month to years, centuries or even millennia (Kirchman, 1993; Carlson and Ducklow, 1995; Anderson and Williams, 1999; Hansell, 2013). Only a small fraction of marine DOC is considered reactive: $\operatorname{LDOC}(<0.2 \mathrm{Gt})$ and SLDOC (6 $\pm 2 \mathrm{Gt})$ (Hansell, 2013). In general, these compounds are freshly produced by plankton and represent the major nutritional resource for heterotrophic microorganisms (Cherrier et al., 1996; Amon and Benner, 1996; Amon et al., 2001; Benner, 2002; Azam and Malfatti 2007; Davis et al., 2009). Especially during the summer season, SLDOC can accumulate in temperate waters, becoming available for deep convective mixing, contributing to the biological carbon pump (Hopkinson and Vallino, 2005; Hansell et al., 2009). Microbial assimilation of DOC, as well as the formation of gel particles, such as transparent exopolymer particles (TEPs), leads to a repartitioning of DOC into the particulate organic carbon (POC) pool (Alldredge et al., 1993; Chin et al., 1998; Engel et al., 2004), the sinking of which represents 
another pathway for carbon export and storage in the ocean. In addition, microbial processing of fresh DOC may result in formation of recalcitrant compounds with longer residence time, also increasing the carbon dioxide $\left(\mathrm{CO}_{2}\right)$ storage potential in the ocean (Jiao and Zheng, 2011). Thus, deeper insights into the origin and quality of DOC in the ocean can greatly abet our ability to quantify carbon and nutrient cycling in the ocean.

The ultimate source of organic carbon in the ocean is primary production, and extracellular release (ER, also referred to as dissolved primary production) of organic carbon is the primary source of fresh DOC, followed by cell lysis (Fuhrman, 1999), grazing (Møller, 2005), enzymatic particle solubilization (Cho and Azam, 1988; Smith et al., 1992) and sloppy feeding (Copping and Lorenzen, 1980; Nagata, 2000). The major components of phytoplankton ER are highmolecular-weight (HMW, $>1 \mathrm{kDa}$ ) dissolved combined carbohydrates $(d \mathrm{CCHO})$, representing also the largest characterizable fraction of marine dissolved organic matter (DOM): $15-35 \%$ DOC in the surface ocean and 5-10\% DOC in the deep ocean (Benner et al., 1992; Pakulski and Benner, 1994; Biddanda and Benner, 1997; Ogawa and Tanoue, 2003). Composition of HMW- $d$ CCHO in seawater is usually determined on the basis of monomeric sugars after hydrolysis of the polymer chains, and resembles either phytoplankton biomass itself (Pakulski and Benner, 1994; Børsheim et al., 1999) or extracellular CCHO from phytoplankton cultures (Biersmith and Benner, 1998; Aluwihare and Repeta, 1999; Aluwihare et al., 2002). The latter are usually comprised of neutral hexoses, pentoses and deoxy sugars like glucose, galactose and mannose; by amino sugars like glucosamine and galactosamine; and by uronic acids, e.g., galacturonic acid and glucuronic acid (Aluwihare et al., 1997; Biersmith and Benner, 1998; Aluwihare and Repeta, 1999; Engel et al. 2010, Borchard and Engel, 2012).

ER is a normal function of healthy algae cells during all stages of growth (Fogg, 1966; Mague et al., 1980; Bjørnsen, 1988; Borchard and Engel, 2012; Lopez-Sandoval et al., 2011) and can comprise up to $80 \%$ of primary production (Sharp, 1977; Mague, 1980; Fogg, 1983; Bjørnsen, 1988). Two conceptual models have been proposed for phytoplankton ER: (i) the passive diffusion model that describes the leakage of smaller molecules from inside the cell to its surrounding environment (Fogg, 1983; Bjørnsen, 1988), and (ii) the overflow model that assumes an energy consuming exudation of HMW compounds (Fogg, 1983; Nagata, 2000; Schartau et al., 2007). According to the passive diffusion model, DOC crosses the cell membrane independently from primary production (PP) during day and night, and ER correlates to phytoplankton biomass and cell size. A higher relative contribution of ER to total PP would therefore be expected in communities dominated by small cells due to their higher surface-to-volume ratio (Bjørnsen, 1988; Kiørboe and Hansen, 1993; Marañón et al., 1996).
Central aspects of the overflow model are a dependence of ER on PP rates, the absence of ER at night and a high share of HMW substances (Williams, 1990, and references therein; Nagata, 2000). Fogg (1966) proposed that photosynthesis and build-up of organic carbon is primarily regulated by irradiance, while cell growth is controlled by the availability of inorganic nutrients. The discharge of photosynthesates not utilized for cell growth was suggested to be more energy efficient than intracellular storage (Wangersky, 1978; Wood and van Valen, 1990). In accordance with the overflow model, data from coastal, marine and estuarine systems revealed a linear relationship between PP and ER, and factors influencing PP were suggested to also affect ER (Baines and Pace, 1991). Such effects were shown for light (Zlotnik and Dubinsky, 1989) and later also suggested for $\mathrm{CO}_{2}$ (Engel, 2002) and temperature (Moran et al., 2006). Under nutrient limitation, however, substantial ER was observed when PP was reduced, leading to higher percentage of extracellular release (PER) (Myklestad et al., 1989; Goldman et al., 1992; Obernosterer and Herndl, 1995; Halewood et al., 2012). Under such conditions, decoupled from PP and biomass, ER becomes difficult to estimate, both in terms of quantity and quality. Moreover, phytoplankton cells display a large physiological plasticity for nutrient requirements, i.e., the nutrient cell quota, which varies with environmental conditions or among different taxonomic groups (Geider and LaRoche, 2002).

Despite their role in marine carbon cycling, processes involved in the production, consumption and remineralization of extracellular organic matter are little understood and have largely been neglected in biogeochemical models (Flynn et al., 2008; Repeta and Aluwihare, 2006; Hansell et al., 2009; Hansell, 2013). So far, it is not known whether extracellular products are mainly released by leakage or by exudation processes, or how much leakage and exudation products differ. We also do not know whether and how the physiological status of the cell influences the composition of extracellular products, and whether or not such differences in chemical signatures subsequently affect their microbial cycling, remineralization rate or affinity to form gel particles.

In order to improve our understanding on ER, we conducted a chemostat experiment with $E$. huxleyi under fully controlled nutrient supply and growth rate. Emiliania huxleyi is a bloom-forming cosmopolitan coccolithophore species, and known to produce a methylated, acidic polysaccharide that plays a central role in coccolith formation and agglutination (Fichtinger-Schepmann, 1979; De Jong, 1979). ER by E. huxleyi cells was reported earlier (Aluwihare and Repeta, 1999; Biddanda and Benner, 1997; Borchard and Engel, 2012) and carbohydrates were shown to provide a substantial fraction of freshly produced HMW-DOC (35-94\%) (Aluwihare and Repeta, 1999; Biddanda and Benner, 1997).

This study was part of a larger experiment investigating carbon and nutrient cycling under different $p \mathrm{CO}_{2}$ conditions at steady-state growth in $E$. huxleyi. No effect of the $\mathrm{CO}_{2}$ 
treatment was observed for elemental stoichiometry of cells as well as for TEP production (Engel et al., 2014). This study focuses on primary production of POC and DOC by E. huxleyi, the carbohydrate composition of cells and for the first time on different size fractions of released compounds.

With our study we wanted (i) to determine ER of DOC and carbohydrates by combining rate measurements for particulate and dissolved primary production with analyses of carbohydrate concentration, and (ii) to characterize monomeric carbohydrate composition in different size classes of DOC in order to elucidate mechanisms of ER. We chose the continuous culture approach, because here cells can be grown under nutrient limitation at steady-state biomass. Thus, in a chemostat the increase in extracellular organic matter can primarily be attributed to growing phytoplankton cells and not to cell lysis and decay, processes that co-occur with ER when batch cultures or natural populations become nutrient depleted.

\section{Methods}

\subsection{Experimental setup}

A calcifying strain of E. huxleyi (PML B92/11) was grown as a continuous culture in two chemostats $(\sim 9.2 \mathrm{~L}$ each) at a constant dilution rate of $D=0.2 \mathrm{~d}^{-1}$. A more detailed description of the chemostat principle and the experimental setup are given by Borchard et al. (2011), respectively. Temperature was set to $14.0 \pm 0.1^{\circ} \mathrm{C}$. Irradiance was provided at a $16 \mathrm{~h} / 8 \mathrm{~h}$ light / dark cycle with a photon flux density of $19 \mu \mathrm{mol}$ photons $\mathrm{m}^{-2} \mathrm{~s}^{-1}$ (TL-D Delux Pro, Philips; QSL 100, Biospherical Instruments Inc.). Nutrient medium was prepared from sterile-filtered (Sartobran P, $0.2 \mu \mathrm{m}$ capsule, Sartorius) aged natural seawater (NSW) with a salinity of 33 , total alkalinity (TA) of $225 \mu \mathrm{mol} \mathrm{kg}^{-1}$ seawater and a $\mathrm{pH}$ of 8.24. The seawater was enriched with nutrients according to the $f / 2$ recipe of Guillard and Ryther (Guillard and Ryther 1962) with final concentrations of $43 \mu \mathrm{mol} \mathrm{L}-1 \mathrm{NO}_{3}^{-}$ and $1.5 \mu \mathrm{mol} \mathrm{L}{ }^{-1} \mathrm{PO}_{4}^{3-}$. The nutrient medium was treated for $3 \mathrm{~h}$ with UV irradiation (Microfloat 1/0, a.c.k. aqua concept $\mathrm{GmbH})$ for sterilization before the addition of sterilefiltered $(0.2 \mu \mathrm{m}$, Minisart, Sartorius) $f / 2$ vitamins. Axenic conditions, however, could not be maintained in the $9.2 \mathrm{~L}$ chemostats over the long period of time.

Equilibration of the medium with $\mathrm{CO}_{2}$ was obtained by constant aeration with 380 and $75 \mu$ atm $\mathrm{CO}_{2}$, respectively. To minimize effects of calcification by E. huxleyi on carbonate chemistry in the incubators, TA in the reservoir tank was increased by addition of bicarbonate (LaRoche et al., 2010), resulting in $2460 \mu \mathrm{mol} \mathrm{kg}^{-1}$ seawater. E. huxleyi cells were pre-cultured for 30 days at prescribed $\mathrm{CO}_{2}$ concentrations and temperature conditions in $f / 2$ media in order to avoid short-term stress effects on cell physiology. Each chemostat incubator was then inoculated to a final density of $\sim 5000$ cells $\mathrm{mL}^{-1}$. Cultures were grown in batch mode for 5 days until the constant medium supply was applied at a dilution rate $(D)$ of $D=0.2 \mathrm{~d}^{-1}$. Cells were kept in suspension by gentle mixing at $50 \mathrm{rpm}$. Here, we report data derived from samplings during steady-state growth on experimental day $30,34,38,42$ and 44 for ${ }^{14} \mathrm{C}$ rate measurements and on day 38, 42 and 44 for carbohydrate analyses and size fractionations of those and ${ }^{14} \mathrm{C}$ exudation. All samples were taken $3 \mathrm{~h}$ after lights-on to avoid biases due to physiological variations during the day-night cycle.

\subsection{Cell density and chemical analysis}

Cell density was determined daily as the mean of three consecutive measurements of $50 \mu \mathrm{L}$ by an electronic particle counter (Coulter Multisizer III, Beckman Coulter) equipped with a $10 \mu \mathrm{m}$ aperture. In order to dilute the samples to 1 : 100, $0.2 \mu \mathrm{m}$ of pre-filtered (Minisart, 2000; Sartorius) NSW with a salinity of 33 was used. After microscopic inspection, particles with an equivalent spherical diameter in a range of 3.2 to $8 \mu \mathrm{m}$ were identified as E. huxleyi cells.

Nutrient samples were filtered through $0.2 \mu \mathrm{m}$ syringe filters (Minisart, Sartorius) and stored frozen at $-20^{\circ} \mathrm{C}$ until analysis. Measurements of $\mathrm{NO}_{3}^{-}, \mathrm{NO}_{2}^{-}, \mathrm{NH}_{4}^{+}$and $\mathrm{PO}_{4}^{3-}$ were made spectrophotometrically after Grasshof et al. (1999) using an Evolution 3 autoanalyzer (Alliance Instruments). Detection limits were $0.3 \mu \mathrm{mol} \mathrm{L}-1$ for $\mathrm{N}$ and $0.01 \mu \mathrm{mol} \mathrm{L}^{-1}$ for P.

Primary production and exudation were measured by applying the ${ }^{14} \mathrm{C}$ incubation method according to Steemann Nielsen (Steemann Nielsen, 1952) and Gargas (Gargas, 1975). Triplicate samples $(75 \mathrm{~mL}$ each) were taken from each chemostat, transferred into cell culture flasks $\left(25 \mathrm{~cm}^{2}\right.$, Corning $\left.{ }^{\circledR}\right)$ and spiked with approximately $5 \mu \mathrm{Ci} \mathrm{NaHCO}-$ (Hartmann Analytics, specific activity 40$60 \mathrm{mCi} \mathrm{mmol}^{-1}$ ). Each triplicate set was incubated for about $4 \mathrm{~h}$ at original experimental light and temperature settings, but without aeration. Simultaneously, dark uptake was measured in triplicate from $75 \mathrm{~mL}$ samples incubated in the dark. Added activity in the samples was determined by removing a $10 \mu \mathrm{L}$ aliquot from three dark bottles prior to incubation and transferred to $6 \mathrm{~mL}$ liquid scintillation vials in which $200 \mu \mathrm{l}$ of $2 \mathrm{~N} \mathrm{NaOH}$ was placed. Four milliliters of liquid scintillation cocktail (Ultima Gold AB) was added before counting. Incubations were stopped by gentle filtration on $0.4 \mu \mathrm{m}$ polycarbonate filters (Nucleopore) at low vacuum ( $<150 \mathrm{mbar})$ to avoid cell breakage. The filters $\left(\mathrm{PO}^{14} \mathrm{C}\right)$ were covered with $25 \mu \mathrm{l}$ of $1 \mathrm{M} \mathrm{HCl}$ in order to remove inorganic ${ }^{14} \mathrm{C}$. After a few seconds they were rinsed with $10 \mathrm{~mL}$ of filtered seawater. Filters were transferred to $6 \mathrm{~mL}$ scintillation vials, $4 \mathrm{~mL}$ of liquid scintillation cocktail (Ultima Gold AB) was added, and samples were stored overnight before being counted in a Packard Tri Carb Liquid Scintillation Counter. Carbon incorporation rates were calculated in accordance to Borchard and Engel (2012). 
Table 1. Definition of size classes for fractionated high-molecular-weight (HMW, $>1 \mathrm{kDa}$ ) dissolved combined carbohydrates (HMW$d \mathrm{CCHO})$ and dissolved organic carbon $\left(\mathrm{DO}^{14} \mathrm{C}\right)$.

\begin{tabular}{lll}
\hline & HMW- $d$ CCHO & $\mathrm{DO}^{14} \mathrm{C}$ \\
\hline Total & $1 \mathrm{kDa}<\mathrm{HMW}-d \mathrm{CCHO}<0.45 \mu \mathrm{m}$ & $\mathrm{DO}^{14} \mathrm{C}<0.40 \mu \mathrm{m}$ \\
Very large & $1000 \mathrm{kDa}<\mathrm{HMW}-d \mathrm{CCHO}<0.45 \mu \mathrm{m}$ & $1000 \mathrm{kDa}<\mathrm{DO}^{14} \mathrm{C}<0.40 \mu \mathrm{m}$ \\
Large & $100 \mathrm{kDa}<\mathrm{HMW}-d \mathrm{CCHO}<1000 \mathrm{kDa}$ & $100 \mathrm{kDa}<\mathrm{DO}^{14} \mathrm{C}<1000 \mathrm{kDa}$ \\
medium & $10 \mathrm{kDa}<\mathrm{HMW}-d \mathrm{CCHO}<100 \mathrm{kDa}$ & $10 \mathrm{kDa}<\mathrm{DO}^{14} \mathrm{C}<100 \mathrm{kDa}$ \\
Small & $1 \mathrm{kDa}<\mathrm{HMW}-d \mathrm{CCHO}<10 \mathrm{kDa}$ & $\mathrm{DO}^{14} \mathrm{C}<10 \mathrm{kDa}$ \\
\hline
\end{tabular}

For the determination of released dissolved organic carbon $\left(\mathrm{DO}^{14} \mathrm{C}\right), 4 \mathrm{~mL}$ of the filtrate was transferred into $20 \mathrm{~mL}$ scintillation vials and acidified to $\mathrm{pH}<2$ by the addition of $10 \mu \mathrm{L}$ of $1 \mathrm{M} \mathrm{HCl}$ and left open under the fume hood for $24 \mathrm{~h}$. For size fractionation of $\mathrm{DO}^{14} \mathrm{C}$, triplicate sets of $10 \mathrm{~mL}$ sample were transferred into Macrosep ${ }^{\circledR}$ centrifugal devices with a membrane cut-off of $<1000,<100$ and $<10 \mathrm{kDa}$, respectively. After centrifugation (Heraeus, Megafuge ${ }^{\circledR} 1.0 \mathrm{R}$ ) for $15 \mathrm{~min}$ at $4000 \mathrm{rpm}, 4 \mathrm{~mL}$ of sample was transferred into $20 \mathrm{~mL}$ liquid scintillation vials. In the following, samples were treated as the whole $\mathrm{DO}^{14} \mathrm{C}$ samples and after the outgassing of inorganic ${ }^{14} \mathrm{C}, 15 \mathrm{~mL}$ of liquid scintillation cocktail was added. Counting and calculations were performed following Borchard and Engel (2012).

Primary production (PP) was derived from the sum of $\mathrm{PO}^{14} \mathrm{C}$ and $\mathrm{DO}^{14} \mathrm{C}$. The $\mathrm{PER}$ was calculated as $\left(\mathrm{DO}^{14} \mathrm{C} / \mathrm{PP}\right) \times 100$.

Total combined carbohydrates $(t \mathrm{CCHO})$ and highmolecular-weight (HMW; > $1 \mathrm{kDa}$ ) dissolved combined carbohydrates $(d \mathrm{CCHO})$ were determined by ion chromatography after Engel and Händel (2011). Duplicate samples for HMW- $d$ CCHO were filtered through $0.45 \mu \mathrm{m}$ syringe filters (GHP membrane, Acrodisk, Pall Corporation) and stored in combusted $\left(8 \mathrm{~h}\right.$ at $\left.500^{\circ} \mathrm{C}\right)$ glass vials at $-20^{\circ} \mathrm{C}$. Samples for $t \mathrm{CCHO}$ remained unfiltered and were stored identically.

For size fractionation of HMW- $d \mathrm{CCHO}, 10 \mathrm{~mL}$ of sample was transferred into Macrosep ${ }^{\circledR}$ centrifugal devices with a molecular weight cut-off (MWCO) of 1000, 100 and $10 \mathrm{kDa}$, respectively. After centrifugation (Heraeus, Megafuge ${ }^{\circledR} 1.0$ R) for $15 \mathrm{~min}$ at $4000 \mathrm{rpm}$, samples were transferred into combusted $\left(8 \mathrm{~h}\right.$ at $\left.500^{\circ} \mathrm{C}\right)$ glass vials and stored at $-20^{\circ} \mathrm{C}$. Before usage, Macrosep ${ }^{\circledR}$ devices were rinsed twice via centrifugation with ultrapure water to avoid any contamination with carbohydrate compounds in the membrane. Concentrations of CCHO in these blanks were tested to be below the detection limit and therefore did not affect analyses.

Prior to analysis, samples were desalinated by membrane dialysis $\left(1 \mathrm{kDa} \mathrm{MWCO}\right.$, Spectra Por) for $6 \mathrm{~h}$ at $0^{\circ} \mathrm{C}$ and thereafter hydrolyzed with $\mathrm{HCl}$ at a final concentration of $0.8 \mathrm{M}$ for $20 \mathrm{~h}$ at $100^{\circ} \mathrm{C}$ to yield monomeric CHO. Samples were stored at $-20^{\circ} \mathrm{C}$ overnight and then neutralized by acid evaporation $\left(\mathrm{N}_{2}\right)$ at $50^{\circ} \mathrm{C}$. Dried samples were solubilized in ultrapure water before determination of $\mathrm{CHO}$ monomers by high-performance anion exchange chromatography (HPAEC) coupled with pulsed amperometric detection (PAD) on a Dionex ICS 3000 (Engel and Händel 2011). A Dionex CarboPac PA10 guard column $(2 \times 50 \mathrm{~mm})$ coupled to a Dionex CarboPac PA10 analytical column $(2 \times 250 \mathrm{~mm})$ was applied for separation of fucose (Fuc), rhamnose (Rha), arabinose (Ara), galactosamine ( $\mathrm{GalN})$, glucosamine $(\mathrm{GlcN})$, galactose (Gal), glucose (Glc), mannose/xylose (Man / Xyl) (quantified together due to coelution), galacturonic acid (GalURA) and glucuronic acid (Glc-URA). Detection limits are $10 \mathrm{nM}$. Particulate CCHO ( $p$ CCHO) was derived from subtraction of HMW- $d \mathrm{CCHO}$ from $t \mathrm{CCHO}$ and thus represent carbohydrates in the size fraction $>0.45 \mu \mathrm{m}$. Concentrations of $\mathrm{CHO}$ are given as $\mu \mathrm{mol}$ carbon per volume of seawater ( $\mu$ mol $\mathrm{CL}^{-1}$ ) and composition of $\mathrm{CCHO}$ is expressed as mol \% CCHO.

Size fractions of $\mathrm{DO}^{14} \mathrm{C}$ and $\mathrm{HMW}-d \mathrm{CCHO}$ obtained using Macrosep ${ }^{\circledR}$ centrifugal devices were subtracted from each other in order to present data for each size class. Definitions for size classes are given in Table 1.

For total alkalinity (TA), $25 \mathrm{~mL}$ of each sample was measured by titrating with $0.05 \mathrm{M} \mathrm{HCl}$ until the buffering capacity of the water samples was consumed and all bases of interest were protonated to zero-level species. Analysis was done with an automatic titrator (TitroLine ${ }^{\circledR}$ alpha plus, SI Analytics) equipped with a sample changer (TW alpha plus, SI Analytics) and a piston burette (Titronic ${ }^{\circledR} 110$ plus, SI Analytics). The $\mathrm{pH}$ was monitored by a two-point-calibrated (buffer solution $\mathrm{pH} 4.006$ and $\mathrm{pH}$ 6.865; Applichem, standardized according to DIN 19266) electrode (Schott ${ }^{\circledR}$ Instruments IoLine). The concentration of TA in $\mu$ mol kg ${ }^{-1}$ seawater was calculated from linear regression of the absolute numbers of protons in solution and the total volume (sample plus $\mathrm{HCl}$ ) in the range of $\mathrm{pH} 4$ and 3. Determination of the seawater carbonate chemistry was conducted using the program CO2SYS (Lewis and Wallace 1998), with pH (calibrated using reference materials provided by A. Dickson) and TA being the input parameters.

\subsection{Data treatment}

All samplings were performed during the steady-state period of the experiment, when the growth rate $(\mu)$ was equal to 


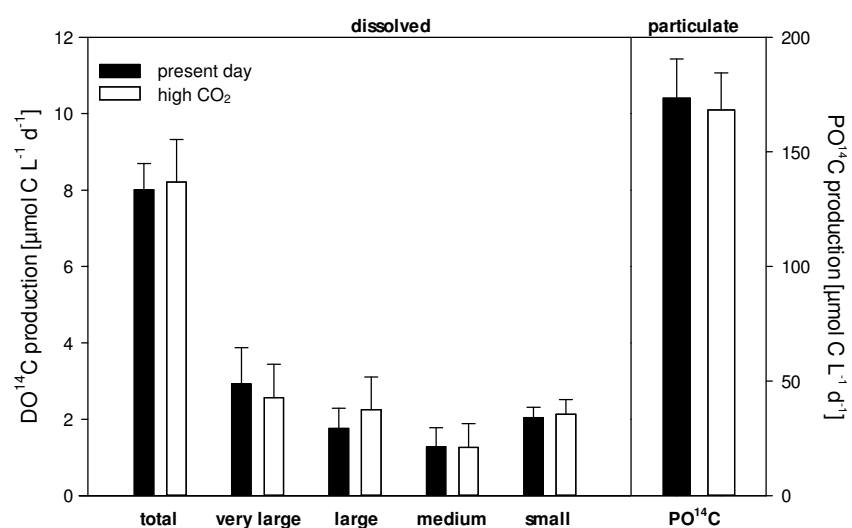

Figure 1. Dissolved $\left(\mathrm{DO}^{14} \mathrm{C}\right.$, left) and particulate $\left(\mathrm{PO}^{14} \mathrm{C}\right.$, right) primary production $\left[\mu \mathrm{mol} \mathrm{CL}^{-1} \mathrm{~d}^{-1}\right.$ ] of Emiliania huxleyi at present-day (filled bars) and high- $\mathrm{CO}_{2}$ (open bars) conditions. Daily rates are additionally given for each $\mathrm{DO}^{14} \mathrm{C}$ size fraction. Each bar corresponds to the average ( \pm standard deviation) of replicate samplings (sampling $1-5, n=5$ ) performed during the steadystate period of the experiment.

the dilution rate $(D)$. The samplings over time thus represent replicates of the same physiological state and values of the respective parameters are given as average \pm standard deviation. Since $\mathrm{CO}_{2}$ induced no differences between the presentday and high- $\mathrm{CO}_{2}$ chemostat, they were used as replicate treatments and values are given as mean values with 1 standard deviation if not stated otherwise.

In order to relate daily rates $\left(\mu \mathrm{mol} \mathrm{L} \mathrm{L}^{-1} \mathrm{~d}^{-1}\right)$ directly to concentrations $\left(\mu \mathrm{mol} \mathrm{L}{ }^{-1}\right)$, data were converted into each other by applying a growth rate of $0.2 \mathrm{~d}^{-1}$. For cellnormalized carbon values, concentrations and rates were divided by the cell number.

Differences in carbohydrate composition for the different size fractions were tested by means of analysis of covariance (two-way ANOVA). Differences as a response to $\mathrm{CO}_{2}$ conditions were tested by means of a $t$ test. Statistical significance was accepted for $p<0.05$. All calculations were performed using the software package Sigma Plot 10.01 (SysStat).

\section{Results}

\subsection{Growth, nutrients and carbonate chemistry}

Growth and biogeochemical composition of Emiliania huxleyi as well as carbonate and nutrient chemistry during this chemostat experiment are described in more detail in Engel et al. (2014). Briefly, on day 28 of the experiment, the steady state was reached, with the dilution rate $(D)$ being equal to the growth rate $(\mu)$ of $E$. huxleyi. Cell abundances and basic parameters such as particulate organic carbon (POC), nitrogen (PON), phosphorus (POP) and chlorophyll $a(\mathrm{Chl} a$ ) remained constant until the end of the experiment, proving the constant physiological state of E. huxleyi ( Engel et al., 2014).

During the steady-state period, cell densities were similar in the present-day and high- $\mathrm{CO}_{2}$ treatment and averaged $5.2 \times 10^{8} \pm 18.6$ and $5.1 \times 10^{8} \pm 19.7 \%$ cells L $^{-1}$, respectively. High variations resulted exclusively from intensive sampling between days 42 and 44 . Until day 42 variations did not exceed $11.6 \%$ and biomass production was accepted as balanced growth as a result of controlled nutrient supply. During steady state (days 30-44), both $\mathrm{NO}_{3}^{-}$and $\mathrm{PO}_{4}^{3-}$ concentrations were below the detection limit in both treatments. $\mathrm{P}$ limitation was likely more severe than $\mathrm{N}$-limitation, given a nutrient supply $\mathrm{N}: \mathrm{P}$ ratio of $\sim 29$ and indicated also by PON : POP ratios clearly $>16$ (Engel et al., 2014). $p \mathrm{CO}_{2}$ was calculated from $\mathrm{pH}$ and TA and yielded significantly different values between treatments of $337 \pm 94$ (present day) and $623 \pm 139\left(\right.$ high $\left.\mathrm{CO}_{2}\right) \mu$ atm. Time-averaged values given here differ slightly from those given by Engel et al. (2014), as that study used data from replicate chemostats per $\mathrm{CO}_{2}$ treatment, while only one chemostat per treatment was sampled for the purpose of this study.

\subsection{Primary production and exudation}

As determined for cell densities, $\mathrm{PO}^{14} \mathrm{C}$ and $\mathrm{DO}^{14} \mathrm{C}$ production rates derived from replicate sampling during steady-state growth varied $<11 \%$, confirming the physiological steady state of E. huxleyi grown in the chemostats. $\mathrm{PO}^{14} \mathrm{C}$ produc-

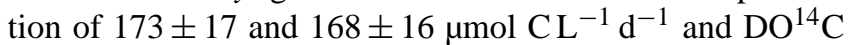
production of $8.0 \pm 0.7$ and $8.2 \pm 1.1 \mu \mathrm{mol} \mathrm{CL}^{-1} \mathrm{~d}^{-1}$ were determined for the present-day and high- $\mathrm{CO}_{2} \mu$ atm treatment, respectively (Fig. 1). Production rates of $\mathrm{PO}^{14} \mathrm{C}$ and $\mathrm{DO}^{14} \mathrm{C}$ were not significantly different between the $\mathrm{CO}_{2}$ treatments (Mann-Whitney rank-sum tests and $t$ tests, $n=$ $5, p>0.69)$ and were thus averaged for both treatments: $171 \pm 16\left(\mathrm{PO}^{14} \mathrm{C}\right)$ and $8.1 \pm 0.9 \mu \mathrm{mol} \mathrm{C} \mathrm{L}{ }^{-1} \mathrm{~d}^{-1}\left(\mathrm{DO}^{14} \mathrm{C}\right)$.

Cell-normalized production of $\mathrm{PO}^{14} \mathrm{C}$ and $\mathrm{DO}^{14} \mathrm{C}$ during the steady-state period was on average $0.33 \pm 0.04$ and $0.015 \pm 0.002 \mathrm{pmol} \mathrm{C}$ cell $^{-1} \mathrm{~d}^{-1}$, respectively for both treatments. Similar $\mathrm{PO}^{14} \mathrm{C}$ and $\mathrm{DO}^{14} \mathrm{C}$ production rates in both chemostats are reflected in comparable PER of $4.42 \pm 0.22$ (present day) and $4.70 \pm 0.92 \%$ (high $\mathrm{CO}_{2}$ ); also, for the size classes of $\mathrm{DO}^{14} \mathrm{C}$, no $\mathrm{CO}_{2}$ effect was determined (Fig. 1).

Averaged for both treatments, size-fractionated (see Table 1 for definition) $\mathrm{DO}^{14} \mathrm{C}$ production ranged between $1.27 \pm 0.53$ (medium) and $2.74 \pm 0.88 \mu \mathrm{mol} \mathrm{C} \mathrm{L}^{-1} \mathrm{~d}^{-1}$ (very large). Relative contribution of different $\mathrm{DO}^{14} \mathrm{C}$ size classes to total $\mathrm{DO}^{14} \mathrm{C}$ was $33.6 \pm 9.31$ (very large), $24.6 \pm 7.90$ (large), $15.9 \pm 7.15$ (medium) and $25.8 \pm 3.55 \%$ (small). Thus, total $\mathrm{DO}^{14} \mathrm{C}$ was comprised of comparable shares of $\mathrm{DO}^{14} \mathrm{C}$ in these size classes with slightly higher proportions in the very large fraction. 
Table 2. Size class resolved production rates of high molecular weight ( $>1 \mathrm{kDa}$ ) carbohydrates (HMW-CCHO) and of fresh organic carbon $\left({ }^{14} \mathrm{C}\right)$ during the chemostat experiment, as well as contribution of carbon contained in HMW-CCHO to primary production $\left({ }^{14} \mathrm{C}\right)$ in particulate matter and in different size fractions of dissolved organic carbon. Values represent averages \pm standard deviation of replicate samplings and both treatments, $n=6$.

\begin{tabular}{|c|c|c|c|c|}
\hline & & $\begin{array}{l}\mathrm{HMW}-\mathrm{CCHO} \\
{\left[\mu \mathrm{mol} \mathrm{C} \mathrm{L}-1 \mathrm{~d}^{-1}\right]} \\
\operatorname{avg} \pm \mathrm{sd}\end{array}$ & $\begin{array}{l}{ }^{14} \mathrm{C} \\
{[\mu \mathrm{mol} \mathrm{C} \mathrm{L}} \\
\quad \text { avg. } \pm \mathrm{d}\end{array}$ & $\begin{array}{c}\text { HMW-CCHO : }{ }^{14} \mathrm{C} \\
{[\%]} \\
\text { avg. } \pm \mathrm{sd}\end{array}$ \\
\hline \multicolumn{2}{|l|}{ Particulate } & $20.7 \pm 5.34$ & $171 \pm 15.9$ & $12.5 \pm 3.54$ \\
\hline \multirow{5}{*}{ Dissolved } & Total & $3.10 \pm 0.41$ & $8.11 \pm 0.88$ & $40.0 \pm 5.37$ \\
\hline & Very Large & $1.41 \pm 0.21$ & $2.74 \pm 0.88$ & $59.7 \pm 17.2$ \\
\hline & Large & $0.71 \pm 0.24$ & $2.01 \pm 0.72$ & $44.6 \pm 24.7$ \\
\hline & Medium & $0.62 \pm 0.25$ & $1.27 \pm 0.53$ & $52.9 \pm 33.7$ \\
\hline & Small & $0.62 \pm 0.18$ & $2.09 \pm 0.32$ & $29.5 \pm 9.30$ \\
\hline
\end{tabular}

\subsection{Combined carbohydrates}

Initial HMW- $d \mathrm{CCHO}$ concentrations of $7.02 \pm 0.15 \mu \mathrm{mol}$ $\mathrm{CL}^{-1}$ were determined in the natural seawater (NSW) media. Corrected for NSW values, carbohydrate concentration during steady-state growth of Emiliania huxleyi was $103 \pm 28$ (present day) and $104 \pm 31 \mu \mathrm{mol} \mathrm{CL}^{-1}$ (high $\mathrm{CO}_{2}$ ) for $p \mathrm{CCHO}$, and $15.2 \pm 2.1$ (present day) and $15.8 \pm 2.4 \mu \mathrm{mol} \mathrm{CL}^{-1}$ (high $\mathrm{CO}_{2}$ ) for fresh HMW$d \mathrm{CCHO}$, and hence very similar between the two $\mathrm{CO}_{2}$ treatments (Fig. 2). Averaged for both treatments, $87 \pm 3 \%$ of $t \mathrm{CCHO}$ was present in the particulate fraction $(p \mathrm{CCHO})$. E. huxleyi produced $p \mathrm{CCHO}$ on the order of $104 \pm 27 \mu \mathrm{mol} \mathrm{CL^{-1 }}\left(0.20 \pm 0.02\right.$ pmol C cell $\left.{ }^{-1}\right)$, equivalent to $20.7 \pm 5.3 \mu \mathrm{mol} \mathrm{C} \mathrm{L}{ }^{-1} \mathrm{~d}^{-1}$ at a growth rate of $0.2 \mathrm{~d}^{-1}$, representing about $12.5 \%$ of the daily produced $\mathrm{PO}^{14} \mathrm{C}$ (Table 2). Freshly produced HMW- $d$ CCHO was $15 \mu \mathrm{mol} \mathrm{C} \mathrm{L}^{-1}$

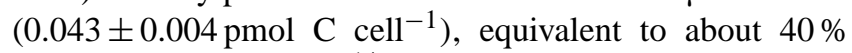
of freshly produced $\mathrm{DO}^{14} \mathrm{C}$. Fresh carbohydrate concentrations in various size classes (see Table 1 for definition) also revealed a strong similarity between the present-day and the high- $\mathrm{CO}_{2}$ treatment (Fig. 2, $t$ tests, $n=6, p>0.269$ ) and are therefore given as average values in the following. In the different size classes, $\mathrm{HMW}-d \mathrm{CCHO}$ comprised between $29.5 \pm 9.3 \%$ (small) and $59.7 \pm 17.2 \%$ (very large) of $\mathrm{DO}^{14} \mathrm{C}$ (Table 2).

HMW- $d$ CCHO yielded $7.07 \pm 1.06$ (very large), $3.57 \pm 1.21 \quad$ (large), $\quad 3.08 \pm 1.26 \quad$ (medium) and $3.09 \pm 0.92 \mu \mathrm{molCL}^{-1}$ (small), suggesting that freshly released HMW- $d \mathrm{CCHO}$ was primarily comprised of very large HMW- $d \mathrm{CCHO}(46 \pm 3 \% \mathrm{C})$. HMW- $d \mathrm{CCHO}$ in the large, medium and size fractions contributed $23 \pm 6,20 \pm 4$ and $20 \pm 3 \% \mathrm{C}$, respectively, to total HMW- $d \mathrm{CCHO}$.

Size fractionation of HMW- $d \mathrm{CCHO}$ in NSW yielded concentrations of $2.39 \pm 0.21$ (very large), $1.31 \pm 0.09$ (large), $1.28 \pm 0.09$ (medium) and $1.95 \pm 0.10 \mu \mathrm{mol} \mathrm{CL}^{-1}$ (small) (Fig. 3a, left panel). During the experiment, extracellular release by $E$. huxleyi enriched the NSW to HMW- $d \mathrm{CCHO}$

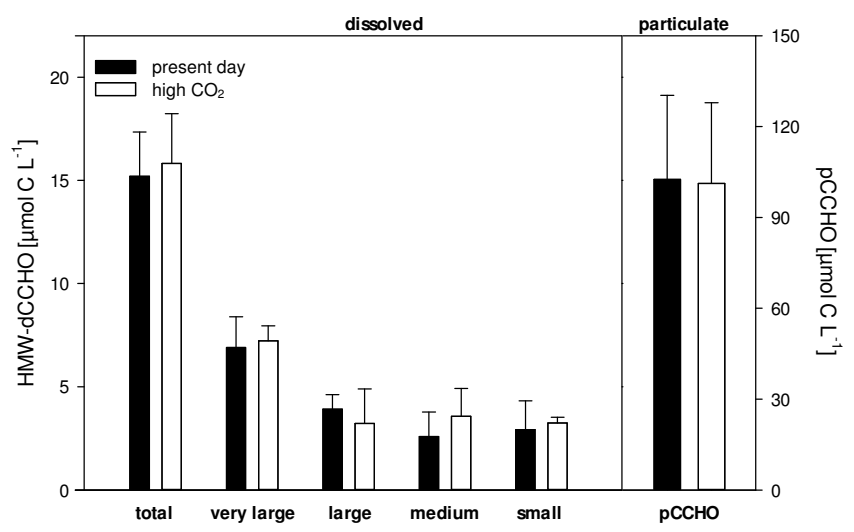

Figure 2. Freshly produced high-molecular-weight (HMW $>1 \mathrm{kDa}$ ) dissolved combined carbohydrates (HMW- $d$ CCHO, left),

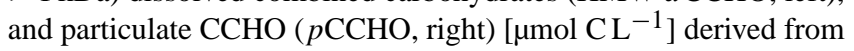
E. huxleyi under present-day (filled bars) and high- $\mathrm{CO}_{2}$ (open bars) conditions. Concentrations are additionally given for each size fraction of HMW- $d$ CCHO. Each bar corresponds to the average ( \pm standard deviation) of replicate samplings (samplings $3-5, n=3$ ) performed during the steady-state period of the experiment.

concentrations of $22.2 \pm 2.1 \mu \mathrm{mol} \mathrm{C} \mathrm{L}{ }^{-1}$ with size fractions of $8.55 \pm 1.08$ (very large), $4.64 \pm 1.33$ (large), $4.09 \pm 1.21$ (medium) and $5.18 \pm 0.72 \mu \mathrm{mol} \mathrm{C} \mathrm{L}{ }^{-1}$ (small) (Fig. 3a, right panel).

\subsection{Carbohydrate composition of exudates}

Sugar monomers of three different types comprised the combined carbohydrates $(\mathrm{CCHO})$ determined during the present experiment: neutral sugars (Fuc, Rha, Ara, Gal, Glc and coeluting Man / Xyl), amino sugars (GalN and GlcN) and uronic acids (Gal-URA and Glc-URA). Various amounts of these monomers were detected in HMW- $d \mathrm{CCHO}$ of the initial NSW used for the present experiment (Fig. 3b, left panel). Size fractions of HMW- $d$ CCHO in NSW did not show any significant variation in monomeric composition 


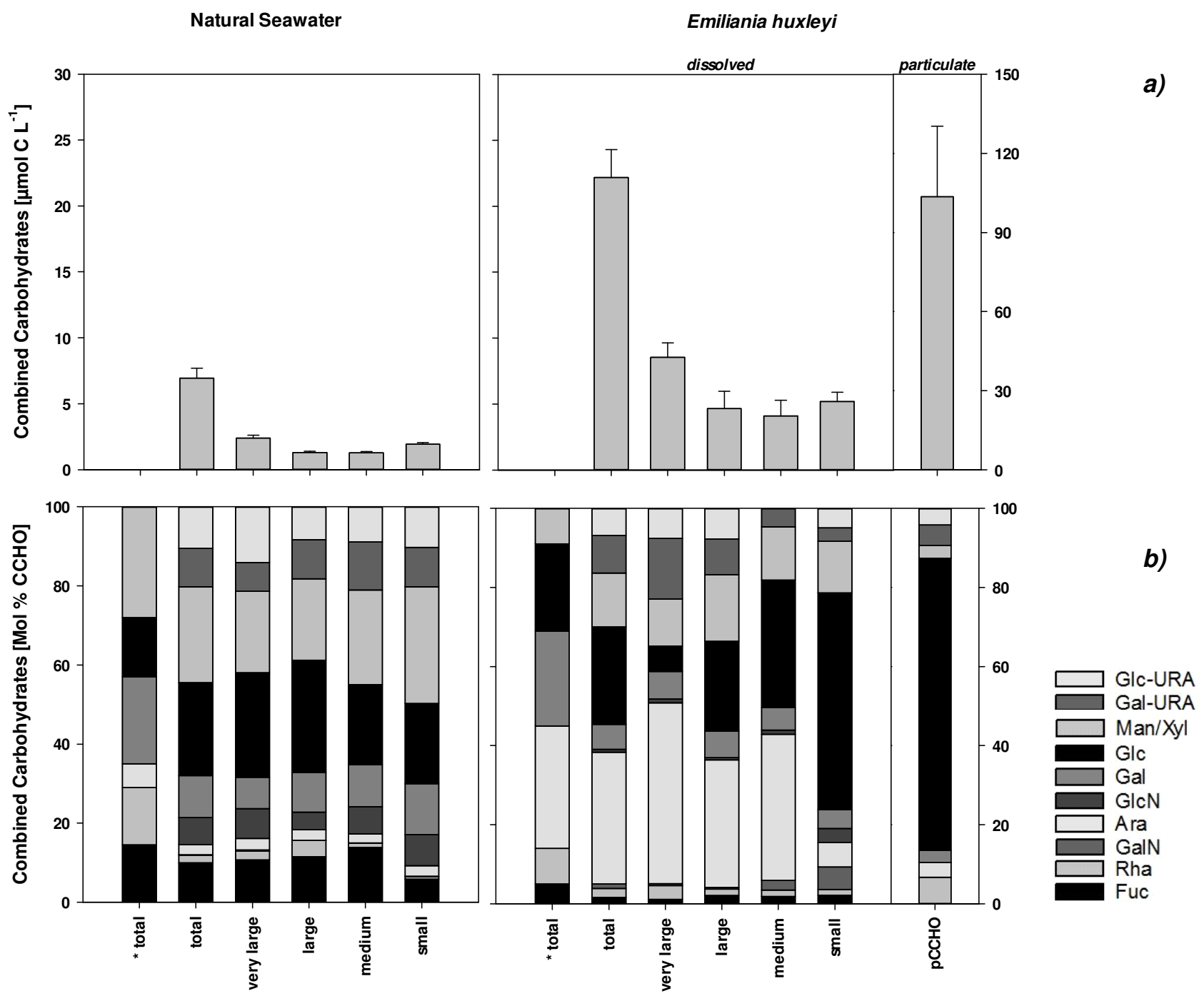

Figure 3. Concentration [ $\mu \mathrm{mol} \mathrm{CL}^{-1}$ ] (a) and composition [mol\% CCHO] (b) of high-molecular-weight (>1 kDa) dissolved combined carbohydrates (HMW- $d \mathrm{CCHO}$ ). Data are shown for natural seawater used to prepare the experimental culture media (left panels) and composition in natural seawater enriched with freshly produced HMW- $d$ CCHO derived from $E$. huxleyi (rights panels) grown in chemostats. Due to the strong similarity between the present-day and high- $\mathrm{CO}_{2}$ treatment, both were treated as replicates. Stacked bars show the average of replicate samplings (samplings 3-5, $n=6$ ) performed during the steady-state period of the experiment.

Data for HMW- $d$ CCHO for natural seawater and E. huxleyi taken from Aluwihare (1999) for comparison. Here, only neutral carbohydrates are included, since amino and acidic HMW- $d \mathrm{CCHO}$ were not analyzed.

$(p>0.462)$. However, relative to the other size fractions Man / Xyl was slightly enriched in the small size fraction, while a smaller proportion of Fuc was detected in this fraction. No significant differences in monomeric composition of $\mathrm{CCHO}$ produced by Emiliania huxleyi were determined between the present-day and high- $\mathrm{CO}_{2}$ treatment $(p>0.881)$. Therefore, average values are given for replicate sampling during steady-state growth and both treatments in the following (Fig. 3 and Table 3).

ER by E. huxleyi led to a clear change in HMW$d \mathrm{CCHO}$ composition of the NSW (Fig. 3b), primarily caused by Ara being significantly higher $(p<0.001)$ in all size classes, except for small (Fig. 3b). In HMW- $d$ CCHO derived from E. huxleyi, Ara and Glc were the dominant sugars, at 46 and $21 \mathrm{~mol} \%$, respectively, followed by Gal-URA (11 mol \%), Man / Xyl $(10 \mathrm{~mol} \%)$, Glc-URA (5.7 $\mathrm{mol} \%)$, Gal $(4.6 \mathrm{~mol} \%)$ and Rha $(2.4 \mathrm{~mol} \%)$ (Table 3 and Fig. 3b, right panel). Proportions of other monomers comprised less than $0.5 \mathrm{~mol} \%$ and declined in the following order: Fuc $>$ GalN $>$ GlcN (Table 3). In $p$ CCHO, Glc was the most abundant sugar $(74 \pm 4 \mathrm{~mol} \%)$, followed by Rha $(6.6 \pm 0.8 \mathrm{~mol} \%)$ and Gal-URA $(5.2 \pm 0.7 \mathrm{~mol} \%)$. 


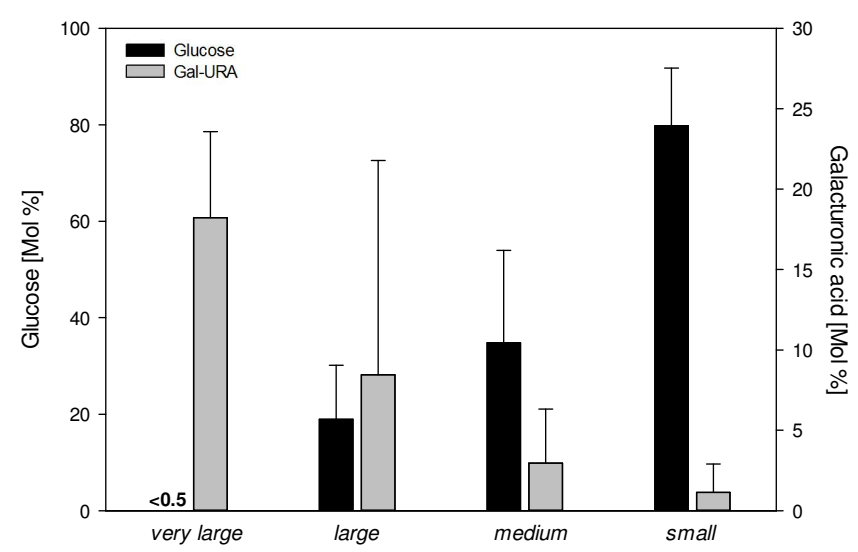

Figure 4. Proportions of glucose (Glc) and galacturonic acid (GalURA) in high-molecular-weight (HMW $>1 \mathrm{kDa}$ ) dissolved combined carbohydrates $(d \mathrm{CCHO})$ of different molecular weight size classes as defined in Table 1. Due to the strong similarity between the present-day and high- $\mathrm{CO}_{2}$ culture, both were treated as replicates. Bars show the average ( \pm standard deviation) of replicate samplings (sampling 3-5, $n=6$ ) performed during the steady-state period of the experiment.

Man / Xyl, Ara and Glc-URA ranged between $3.2 \pm 1.7$ and $4.2 \pm 1.0 \mathrm{~mol} \%$, while Fuc and the amino sugars GalN and GlcN contributed only a minor fraction $(<0.5 \mathrm{~mol} \%)$ to $p$ CCHO (Table 3).

Hence, composition of $p \mathrm{CCHO}$ was substantially different from the composition determined for freshly produced HMW- $d$ CCHO $(p<0.002)$, except for the proportions of Gal and Glc-URA. This difference is mainly attributed to a smaller proportion of Glc in the dissolved fraction along with a more than 10-fold higher share of Ara and also higher proportions of Man / Xyl and Gal-URA (Table 3).

Carbohydrate composition of the investigated $d \mathrm{CCHO}$ size fractions was also significantly different $(p<0.002)$. Ara was dominant in very large, large and medium HMW$d \mathrm{CCHO}$, but not in the small fraction, in which its contribution was significantly smaller than in all other size classes $(p<0.01)$. Most interestingly, the proportion of Glc increased with decreasing size class, while the proportion of Gal-URA clearly decreased (Fig. 4). In the small fraction, Glc contribution was $80 \pm 12 \mathrm{~mol} \%$ and significantly higher than in all other size classes of HMW- $d$ CCHO $(p<0.002)$ (Table 3). The contribution of Glc to very large $d \mathrm{CCHO}$ was negligible $(<0.5 \mathrm{~mol} \%)$. In contrast, Gal-URA contributed $18 \mathrm{~mol} \%$ to the very large fraction, but only $1 \mathrm{~mol} \%$ to the small fraction. Proportions of Gal also decreased with the smaller HMW- $d$ CCHO size classes, albeit not as clearly as for Gal-URA. Gal ranged from 6 (very large) to $<0.5 \mathrm{~mol} \%$ (small). Contributions of Rha and Man / Xyl varied among size classes mol \% of Fuc and both amino sugars as well as GalN and GlcN were negligible.

\section{Discussion}

\subsection{Particulate and dissolved primary production}

Nutrient limitation and low growth rate did not hamper organic carbon production of Emiliania huxleyi during the present study. Cell normalized production of $\mathrm{PO}^{14} \mathrm{C}$ was on average $\sim 0.33 \mathrm{pmol} \mathrm{C}$ cell $^{-1} \mathrm{~d}^{-1}$ and well within the range of published values $\left(0.12-0.64 \mathrm{pmol} \mathrm{C}\right.$ cell ${ }^{-1} \mathrm{~d}^{-1}$; Biddanda and Benner, 1997; Borchard and Engel, 2012). The partitioning of organic carbon between dissolved and particulate pool was shown earlier to be highly influenced by environmental conditions such as light, temperature and nutrient supply (Myklestad and Haug, 1972; Zlotnik and Dubinsky, 1989; Staats et al., 2000; Wetz and Wheeler, 2007). Nutrient depletion, however, seems to be the major factor leading to excess DOC excretion from algae cells to the surrounding environment and was reported from a variety of field and lab experiments (Fogg, 1983; Wood and VanValen, 1990; Smith and Underwood, 2000; Lopez Sandoval, 2010, 2011). Extracellular release (ER) in the range of 0 $80 \%$ has been reported over the past decades, and only after a long-lasting debate primarily concerning methodological constraints (Sharp, 1977; Mague, 1980; Fogg, 1983; Bjørnsen, 1988) has it become accepted today that ER is a normal function of healthy algae cells occurring during all stages of growth. In exponentially growing cells in culture, ER typically ranges between 2 and $10 \%$, while in natural marine environments ER is generally higher by $10-20 \%$ (see Nagata, 2000, and references therein). A relatively constant PER of $20 \%$ was reported for field samples over different ecosystems covering oligotrophic and eutrophic regions (Marañón et al., 2005). Increased PER (up to $37 \%$ ), however, were observed for nutrient-limited algae during the transition period of exponential to stationary growth and during senescence of natural phytoplankton communities (LopezSandoval, 2010, 2011; Engel et al., 2013). In chemostats, despite the strict control of nutrient supply and growth rate, cells still grow exponentially. A decoupling of carbon to nutrient metabolism in continuous cultures can occur due to a change in growth rate (e.g., change the inflow of nutrient media) and results in changes in the partitioning between dissolved and particulate carbon pools, as shown with the same E. huxleyi strain (B 92/11) by Borchard and Engel (2012). In their study, down-regulation of the growth rate from $\mu=0.3 \mathrm{~d}^{-1}$ to $\mu=0.1 \mathrm{~d}^{-1}$ induced a slight increase in $\mathrm{DO}^{14} \mathrm{C}$ production, while the $\mathrm{PO}^{14} \mathrm{C}$ production was significantly minimized, resulting in higher PER. Cells then adapted to the steady state and high PER remained constant. During the present study, growth of E. huxleyi was also balanced to the nutrient supply but cells were not exposed to any stress due to nutritional changes. Thus, production of $\mathrm{DO}^{14} \mathrm{C}$ was not explicitly stimulated by changing experimental conditions, and, albeit constantly P limited, the cell-normalized $\mathrm{DO}^{14} \mathrm{C}$ production of $\sim 0.015 \mathrm{pmol} \mathrm{C}$ cell $^{-1} \mathrm{~d}^{-1}$ represented 
Table 3. Freshly produced combined carbohydrates $(\mathrm{CCHO})$ in various size fractions. Average values (bold) and standard deviations (nonbold) in mol \% CCHO are given for replicate samplings and both treatments, $n=6$. Fuc, GalN and GlcN were always $<0.5 \mathrm{~mol} \%$ and are not included.

\begin{tabular}{lccccccc}
\hline $\begin{array}{l}\text { CCHO [mol \%] } \\
\text { Size fraction }\end{array}$ & Rha & Ara & Gal & Glc & Man / Xyl & Gal-URA & Glc-URA \\
\hline$p$ CCHO & $\mathbf{6 . 5 6}$ & $\mathbf{3 . 6 9}$ & $\mathbf{3 . 0 9}$ & $\mathbf{7 4 . 0}$ & $\mathbf{3 . 2 2}$ & $\mathbf{5 . 1 8}$ & $\mathbf{4 . 2 3}$ \\
& 0.84 & 0.99 & 1.45 & 4.08 & 1.65 & 0.68 & 1.01 \\
HMW-dCCHO & $\mathbf{2 . 4 4}$ & $\mathbf{4 6 . 0}$ & $\mathbf{4 . 6 4}$ & $\mathbf{2 0 . 5}$ & $\mathbf{9 . 6 8}$ & $\mathbf{1 1 . 0}$ & $\mathbf{5 . 7 4}$ \\
(total) & 0.70 & 3.0 & 1.95 & 7.48 & 2.37 & 4.40 & 2.99 \\
Very large & $\mathbf{3 . 4 6}$ & $\mathbf{5 4 . 2}$ & $\mathbf{6 . 3 4}$ & $<\mathbf{0 . 5}$ & $\mathbf{9 . 6 2}$ & $\mathbf{1 8 . 2}$ & $\mathbf{8 . 1 7}$ \\
& 1.88 & 13.3 & 4.11 & - & 6.35 & 5.35 & 6.11 \\
Large & $\mathbf{0 . 9 1}$ & $\mathbf{4 1 . 0}$ & $\mathbf{5 . 9 2}$ & $\mathbf{1 8 . 9}$ & $\mathbf{1 6 . 5}$ & $\mathbf{8 . 4 5}$ & $\mathbf{8 . 3 4}$ \\
& 0.85 & 24.2 & 5.10 & 11.2 & 18.9 & 13.3 & 13.41 \\
Medium & $\mathbf{1 . 7 1}$ & $\mathbf{4 8 . 8}$ & $\mathbf{3 . 5 4}$ & $\mathbf{3 4 . 9}$ & $\mathbf{8 . 2 0}$ & $\mathbf{2 . 9 6}$ & $<\mathbf{0 . 5}$ \\
& 1.03 & 9.41 & 3.41 & 19.2 & 9.88 & 3.35 & - \\
Small & $\mathbf{2 . 2 5}$ & $\mathbf{9 . 7 0}$ & $<\mathbf{0 . 5}$ & $\mathbf{7 9 . 8}$ & $\mathbf{4 . 0 3}$ & $\mathbf{1 . 1 3}$ & $\mathbf{2 . 6 4}$ \\
& 1.54 & 6.17 & - & 11.9 & 3.74 & 3.35 & 2.89 \\
\hline
\end{tabular}

pCCHO: particulate combined carbohydrates; HMW- $d$ CCHO: high-molecular-weight ( $>1 \mathrm{kDa}, \mathrm{HMW}$ ) dissolved combined carbohydrates; Rha: rhamnose; Ara: arabinose; Gal: galactose; Glc: glucose; Man / Xyl: coeluting mannose and xylose; Gal-URA: galacturonic acid; Glc-URA: glucuronic acid.

an ER of $\sim 4.5 \%$, well within the abovementioned range for non-stressed algae. Full acclimation to environmental conditions during steady-state growth may also explain the absence of a $\mathrm{CO}_{2}$ effect on primary production and exudation during this study, and shows that E. huxleyi is in principle capable of acclimating to different $\mathrm{CO}_{2}$ concentrations. Engel et al. (2014) suggested that exudation may be more sensitive to changes in $p \mathrm{CO}_{2}$ during transient growth phase, such as towards the end of phytoplankton blooms, when cells become nutrient limited. Indeed, significant responses of ER to changes in $p \mathrm{CO}_{2}$ have mainly been reported for phytoplankton blooms (Engel et al., 2013), batch and semi-continuous cultures (Thornton, 2009; Barcelos and Ramos, 2014), or when growing conditions changed during chemostat studies (Borchard and Engel 2012).

\subsection{Combined carbohydrate production}

HMW- $d$ CCHO freshly produced by $C$. huxleyi during steady-state growth represented about $40 \%$ of freshly produced $\mathrm{DO}^{14} \mathrm{C}$ (Table 2). This is a lower estimate because low-molecular-weight DOC $(<1 \mathrm{kDa}$, LMW) would be detected with the ${ }^{14} \mathrm{C}$-incubation method (Steemann Nielsen, 1952) during the determination of $\mathrm{DO}^{14} \mathrm{C}$, but would escape the analysis of HMW- $d \mathrm{CCHO}$ due to the molecular cut-off $>1 \mathrm{kDa}$ during desalinization of seawater samples (Engel and Händel, 2011). In the surface ocean, HMW compounds of dissolved organic matter (DOM) were found to be more abundant (30-35\%) compared to deeper waters (20-25\%) and it was concluded that HMW-DOM inherits a higher reactivity and shorter lifetimes, while LMW-DOM is rather refractory (Amon and Benner, 1996; Ogawa and Tanoue, 2003). Major reaction processes of HMW compounds are heterotrophic degradation (Amon and Benner, 1996; Guo et al., 2002; Aluwihare and Repeta, 1999) and gel particle formation (Mari and Burd, 1998; Leppard, 1995; Passow, 2000; Passow, 2002, and references therein). Thus, the HMWDOM pool is directly linked to processes significant for organic carbon dynamics, nutrient cycling and oxygen consumption in the ocean. Assembly and coagulation of polymeric precursors has been proposed as a mechanism leading to the formation of marine gel particles, such as TEPs. Specifically, divalent cation bridging of acidic sugars, such as uronic acids, is assumed to be involved in bonding between polysaccharide chains. The release of larger polysaccharides with relatively high mol \% Gal-URA as observed for $E$. huxleyi in this study may be an important first step for high TEP concentrations observed previously (Engel et al., 2004; Harlay et al., 2009). However, absolute rates of ER were relatively low and apparently insufficient to induce TEP formation during this study. Engel et al. (2014) suggested that responses to variations in environmental factors, specifically to changes in nutrient supply, are responsible for excess carbon accumulation inside the cell and for exudation of carbohydrates. Sampling during this study was conducted during the period of steady-state growth. This may explain the observed relatively low rates of ER, including potential TEP precursors.

\subsubsection{Monomeric composition of $\mathrm{CCHO}$}

NSW used in the present study to prepare the nutrient media was collected from the North Sea and kept under dark and cool conditions for several months before usage. HMW- $d \mathrm{CCHO}$ monosaccharide composition of NSW was dominated by Glc (24 mol\%) 
and Man / Xyl (24 mol\%). Also, high mole percentage $(\sim 10)$ of Fuc, Gal, Gal-URA and Glc-URA were determined, while other monomers were of minor importance (Fig. 3b, left panel). The composition of the aged NSW used here differs from what was obtained from the Northwest Atlantic, the Sargasso Sea and the Gulf of Mexico (Aluwihare et al., 1997, and references therein), especially concerning comparably low proportions of Rha and Gal (Fig. 3b, left panel). Differences in carbohydrate composition of the seawater can be explained by seasonal or geographical divergences as well as by storage time of NSW. Monomeric composition of HMW- $d \mathrm{CCHO}$ released by $E$. huxleyi during the present experiment was substantially different from the initial NSW composition (Fig. 3b) and the compositional shift was primarily induced by a profound relative increase in Ara. The HMW- $d \mathrm{CCHO}$ and $p \mathrm{CCHO}$ derived from $E$. huxleyi during this experiment contained a similar composition as determined earlier for cellular and extracellular carbohydrates derived from this species (De Jong et al., 1979; Fichtinger Schepman et al., 1979; Nanninga et al., 1996; Bilan and Usov, 2001). Cellular $p$ CCHO of $E$. huxleyi clearly differed from not only NSW but also HMW$d \mathrm{CCHO}$ (Fig. 3b, right panel). This is in accordance with previous studies showing differences between intracellular and extracellular CCHO compositions for various algae (Mague, 1980; Aluwihare, 1999, 2002).

Neutral sugars generally dominated the HMW- $d$ CCHO composition with $\sim 83 \mathrm{~mol} \%$. These results are consistent with findings by Aluwihare (1999), who report on HMW exudates from $E$. huxleyi being mainly composed of neutral polysaccharides with Ara as the dominant monomer $(30 \mathrm{~mol} \%)$. However, the fraction of Ara observed during this study is considerably higher than reported for ultrafiltered DOM (>1 kDa) by Biersmith and Benner (1998), who also investigated non-axenic $E$. huxleyi as a batch culture, and for HMW- $d$ CCHO sampled during a field study in the Bay of Biscay where coccolithophores and presumably $E$. huxleyi was the dominating phytoplankton organism (Engel et al., 2012); both studies reported Ara of $\sim 3 \%$ mol. Apart from well-documented species-specific differences in CCHO composition (Aluwihare and Repeta, 1999; Myklestad, 1974; Myklestad et al., 1989), variations in the composition of algal extracellular carbohydrates may be related to physiological and ecological functions. Although freshly produced DOC is generally a primary substrate for heterotrophic uptake, $E$. huxleyi exudates were shown to exhibit recalcitrant features (Nanninga et al., 1996). Degradation experiments with the diatom Thalassiosira weissflogii revealed a special role of Ara in carbohydrate accessibility, as it escaped bacterial degradation over a period of 2 weeks (Aluwihare and Repeta, 1999). Bacterial cell numbers during the present experiment were relatively high, between 2 and $3 \times 10^{6} \mathrm{~mL}^{-1}$, contributing $\sim 2 \%$ to particulate organic carbon (POC) and $\sim 3 \%$ to DOC (Engel et al., 2014). Assuming a bacterial growth efficiency of $60 \%$ (upper limit; Del Giorgio and Cole, 1998), the bacterial carbon demand could have been about $2 \%$ of POC and $5 \%$ of DOC. Relative to the freshly produced $\mathrm{DO}^{14} \mathrm{C}$ derived from rate measurements, however, a share of up to $20 \%$ may have been channeled into heterotrophic turnover. This means that PER would be underestimated by $20 \%$ at most. The HMW-CCHO was thus to some extent subject to bacterial reworking, and the high proportions of Ara may be a result of the selective removal of other monomers. In accordance with the findings of Aluwihare (1999), concentration of Ara in $d \mathrm{CCHO}$ remained unchanged during a degradation experiment with the same E. huxleyi strain investigated here, while $d \mathrm{CCHO}$ was reduced by $\sim 60 \%$ (Piontek et al., 2010; J. Piontek, personal communication, 2014). However, we would expect extensive microbial degradation of larger $d$ CCHO to lead to an increase in Ara mol \% in the small size fraction. However, this was not observed.

Alternatively, high-mol \% Ara and low-mol \% Glc may indeed be a characteristic of larger carbohydrate molecules released by E. huxleyi that are recalcitrant to microbial decomposition. Assuming these components are bad substrates for microbial utilization, their controlled exudation, if physiologically necessary, may be ecologically advantageous for algal cells that are competing with bacteria for nutrients such as phosphorus. This corroborates earlier findings of DOM produced at $\mathrm{P}$ depletion being more resistant to bacterial degradation (Obernosterer and Herndl, 1995; Puddu, 2003). On the other hand, bacteria recycle organic phosphorus, and a certain degree of bacterial activity will be advantageous for regenerated productivity of algal cells. So far, little is known on how nutrient limitation affects the composition of algal release products. We suggest that nutrient availability may be one factor responsible for variability in carbohydrate composition observed during various studies (Giroldo et al., 2005; Goldberg et al., 2010; Engel et al. 2013).

Assuming a certain degree of microbial modification, another explanation for the difference of $\mathrm{CCHO}$ composition between culture studies and those observed in natural seawater may be the highly specific linkage between algal release and bacterial community response, proposed in a series of recent studies (Teeling et al., 2012; Taylor et al., 2014; Kabisch et al., 2014). These studies showed that the release of algal polysaccharides can induce a succession of bacterial communities inhabiting different abilities for enzyme expression related to specific carbohydrate degradation. Because the majority of marine bacteria cannot be kept in culture, bacteria present in this chemostat study, and likely in all culture experiments, represent only a small fraction of the natural diversity. The bacteria present in this study may have left a different fingerprint on polysaccharide composition than natural communities. Short-term incubation studies with natural bacterial communities may be required to better understand the microbial fingerprint on DOM, specifically polysaccharide degradation. A better understanding of the microbial fingerprint on DOM could also allow for tracing microbial degra- 
dation activities in specific environments, such as the ocean's anoxic zones, or the extreme oligotrophic seas.

\subsubsection{Size fractionation of $\mathrm{CCHO}$ and DOC - considerations on extracellular release}

Quantitatively, each $\mathrm{DO}^{14} \mathrm{C}$ size fraction contributed similar amounts to total $\mathrm{DO}^{14} \mathrm{C}$ with slightly higher proportions in the very large fraction (Fig. 1 and Table 2). Release rates of HMW- $d$ CCHO were similar for the different size fractions but highest in the very large fraction (Fig. 2, Table 2). On a total basis, $\sim 40 \%$ of produced $\mathrm{DO}^{14} \mathrm{C}$ was characterized as freshly produced HMW- $d \mathrm{CCHO}$ (Table 2). Contribution of $d \mathrm{CCHO}$ to fresh DOC was lowest in the small size fraction $(30 \%)$ and highest in the very large fraction $(60 \%)$ (Table 2). Monomeric composition of different size classes of $d \mathrm{CCHO}$ enriched by $E$. huxleyi exudates was profoundly different from those of the aged NSW used as culture media (Fig. 3). In aged NSW, monomers were more evenly distributed among size fractions (Fig. 3b, left panel). In comparison, differences in monomeric composition of size classes in E. huxleyi exudates were largely due to changes in Ara, Glc, and Gal-URA. Most remarkably, Ara the dominant monomer in all larger $d \mathrm{CCHO}$ size classes, was of minor importance in the small $d \mathrm{CCHO}$ size fraction and lowest in the particulate fraction (Fig. 3, right panel). This is in accordance with the findings of Biersmith and Benner (1998), who also observed lower mol \% of Ara for particulate components of an E. huxleyi culture as well as for the cell lysate. In contrast to Ara, mol \% of Glc in our study was highest in the particulate and small fraction, relatively small in the medium to large fraction, and negligible in the very large fraction. This also agrees well to earlier findings; Skoog et al. (2008) observed larger mol \% of Glc in LMW-CCHO than in HMW-CCHO, while reporting less mol \% of Ara in LMW-CCHO than in HMWCCHO. Thus, differences in size fractions of combined sugar molecules may be one factor responsible for differences in $\mathrm{CCHO}$ composition of DOC between study sites.

In general, carbohydrate composition in the smallest size class was similar to cellular $p \mathrm{CCHO}$ composition, while larger molecules were more distinct (Fig. 3, right panel). The ${ }^{14} \mathrm{C}$ method (Steemann Nielsen, 1952) applied here to measure primary production and ER of organic carbon does not allow for distinguishing whether DOC is released from the cell passively (i.e., by leakage) or actively (i.e., by exudation). Leakage is hypothesized to be directly related to biomass and cell size, suggesting a constant value of passive PER. The composition of the small size class, and particularly the high share of Glc, resembled the cellular carbohydrate composition (Fig. 3b, right panel). This finding suggests a non-selective, i.e., passive, release of carbohydrates in the smallest size class determined here. Storage glucans in algae are comprised exclusively of Glc in D formation and have a molecular weight of $5-10 \mathrm{kDa}$. D-Glc was reported as a major component of coccolith polysaccharide
(CP) of E. huxleyi (Fichtinger Schepman, 1979). For chloroplasts in higher plants, porins are described that allow transmembrane passage of hydrophilic molecules like sugars and amino acids up to a molecular weight of $10 \mathrm{kDa}$ without the use of energy (Flügge and Benz, 1984; Mohr and Schopfer, 1992). The existence of porins in cell membranes of algae is likely but not explicitly reported. If $\mathrm{DO}^{14} \mathrm{C}>1$ and $<10 \mathrm{kDa}$ and associated carbohydrates leak from the cell in accordance to the passive diffusion model, this extracellular release is presumably linear correlated to biomass ("property tax" - Sharp, 1977). For molecules $>10 \mathrm{kDa}$, however, different mechanisms for the extracellular release are to be expected, since larger molecules cannot pass the membrane by diffusion, and $\mathrm{CCHO}$ composition clearly differs from intracellular CCHO (Fig. 3b, right panel). If active release, i.e., exudation, follows the overflow model, biomass growth and dissolved primary production might be strongly decoupled ("income tax" - Sharp, 1977). Moreover, exudation requires a series of physiological processes involved in the synthesis, transport and trans-membrane release of exudates. Hence, exudates likely vary in composition. Data obtained during the present study indicate that components $>10 \mathrm{kDa}$ rich in Ara and Gal-URA and poor in Glc are transported actively through the cell membrane.

\section{Conclusions}

Carbohydrates of high molecular weight $(>1 \mathrm{kDa})$ as a product of primary production are released from nutrient-limited E. huxleyi during steady-state growth. Compositional differences between size fractions of combined carbohydrate suggest that $d \mathrm{CCHO}>10 \mathrm{kDa}$ is released by active exudation across the cell membrane, whereas lower-molecular-weight carbohydrates $(<10 \mathrm{kDa})$ can pass the membrane passively by leakage. The underlying mechanism of the release, however, needs to be further elucidated. To unravel whether the presence of Ara is indeed an indicator of less degradable exudates, as suggested by this study, or whether Ara degradation requires activities of specific bacterial assemblages, further exploration is needed, i.e., by using axenic phytoplankton cultures combined with the addition of natural bacterioplankton communities. At present our understanding of how microbial processes shape the molecular composition of DOM, specifically of carbohydrates, is still in its infancy. This study suggests that $d \mathrm{CCHO}$ composition and size may be valuable indicators of processes related to autotrophy such as primary production and exudation but that they may also keep the fingerprint of heterotrophic degradation. A better understanding of compositional changes in $d \mathrm{CCHO}$, as a major fraction of semi-labile DOC, may therefore help to unravel carbon cycling and ecosystem dynamics in the ocean.

Acknowledgements. We thank Mascha Wurst, Sonja Endres, Cindy Lee, Carolina Cisternas-Novoa and Tiantian Tang for pro- 
viding samples from the chemostat experiment, and Nicole Händel, Karin Woudsma, Laura Wischnewksi and Jon Roa for technical support. This research was supported by the Helmholtz Association and is a contribution to the German Research Foundation Collaborative Research Centre 754 (DFG SFB754) program "Climate-Biogeochemistry Interactions in the Tropical Ocean" and to the Chemical Oceanography Program of the US National Science Foundation through the ADAGIO project.

The service charges for this open-access publication

have been covered by a research centre of the

Helmholtz Association.

Edited by: G. Herndl

\section{References}

Alldredge, A. L., Passow, U., and Logan, B. E.: The abundance and significance of a class of large, transparent organic particles in the ocean, Deep-Sea Res., 40, 1131-1140, 1993.

Aluwihare, L. I. and Repeta, D. J.: A comparison of the chemical characteristics of oceanic DOM and extracellular DOM produced by marine algae, Mar. Ecol.-Prog. Ser., 186, 105-117, 1999.

Aluwihare, L. I., Repeta, D. J., and Chen, R. F.: A major biopolymeric component of dissolved organic carbon in surface seawater, Nature, 387, 166-169, 1997.

Aluwihare, L. I., Repeta, D. J., and Chen, R. F.: Chemical composition and cycling of dissolved organic matter in the Mid-Atlantic Bight, Deep-Sea Res. Pt. II, 49, 4421-4437, 2002.

Amon, R. M. W. and Benner, R.: Bacterial utilization of different size classes of dissolved organic matter, Limnol. Oceanogr., 41, 41-51, 1996.

Amon, R. M. W., Fitznar, H. P., and Benner, R.: Linkages among the bioreactivity, chemical composition, and diagenetic state of marine dissolved organic matter, Limnol. Oceanogr., 46, 287297, 2001.

Anderson, T. R. and Williams, P. J. L. B.: A one-dimensional model of dissolved organic carbon cycling in the water column incorporating combined biological-photochemical decomposition, Global Biogeochem. Cy., 13, 337-349, 1999.

Azam, F. and Malfatti, F.: Microbial structuring of marine ecosystems, Nat. Rev. Microbiol., 5, 782-791, 2007.

Baines, S. B. and Pace, M. L.: The production of dissolved organic matter by phytoplankton and its importance to bacteria: Patterns across marine and freshwater systems, Limnol. Oceanogr., 36, 1078-1090, 1991.

Barcelos e Ramos, J. and Ramos, J., Schulz, K. G., Brownlee, C., Sett, S., and Azevedo, E. B.: Effects of Increasing Seawater Carbon Dioxide Concentrations on Chain Formation of the Diatom Asterionellopsis glacialis, PLoS ONE, 9, e90749. doi:10.1371/journal.pone.0090749749, 2014.

Benner, R.: Chemical composition and reactivity, in: Biogeochemistry of Marine Dissolved Organic Matter, edited by: Hansell, D. A. and Carlson, C. A., Elsevier Science Academic Press, San Diego, 59-90, 2002.

Benner, R., Pakulski, J. D., McCarthy M., Hedges J. I., Hatcher P. G.: Bulk Chemical Characteristics of Dissolved Organic Matter in the Ocean, Science, 255, 1561-1564, 1992.
Biddanda, B. and Benner, R.: Carbon, nitrogen, and carbohydrate fluxes during the production of particulate and dissolved organic matter by marine phytoplankton, Limnol. Oceanogr., 42, 506518, 1997.

Bilan, M. I. and Usov, A. I.: Polysaccharides of calcareous algae and their effect on the calcification process, Russ. J. Bioorg. Chem., 27, 2-16, 2001.

Biersmith, A. and Benner, R.: Carbohydrates in phytoplankton and freshly produced dissolved organic matter, Mar. Chem., 63, 131144, 1998.

Bjørnsen, P. K.: Phytoplankton exudation of organic matter: Why do healthy cells do it?, Limnol. Oceanogr., 33, 151-154, 1988.

Borchard, C. and Engel, A.: Organic matter exudation by Emiliania huxleyi under simulated future ocean conditions, Biogeosciences, 9, 3405-3423, doi:10.5194/bg-9-3405-2012, 2012.

Borchard, C., Borges, A.V., Händel, N., and Engel, A.: Biogeochemical response of Emiliania huxleyi (PML B92/11) to elevated $\mathrm{CO}_{2}$ and temperature under phosphorous limitation: a chemostat study, J. Exp. Mar. Biol. Ecol., 411, 61-71, 2011.

Børsheim, K. Y., Myklestad, S. M., and Sneli, J. A.: Monthly profiles of DOC, mono- and polysaccharides at two locations in the Trondheimsfjord (Norway) during two years, Mar. Chem., 63, 255-272, 1999.

Carlson, C. A. and Ducklow, H. W.: Dissolved organic carbon in the upper ocean of the central equatorial pacific ocean, 1992 Daily and fine-scale vertical variations, Deep-Sea Res. Pt. II, 42, 639-656, 1995.

Cherrier, J., Bauer J. E., and Druffel, E. R. M.: Utilization and turnover of labile dissolved organic matter by bacterial heterotrophs in eastern north Pacific surface waters, Mar. Ecol.Prog. Ser., 139, 267-279, 1996.

Chin, W. C., Orellana, M. V., and Verdugo, P.: Spontaneous assembly of marine dissolved organic matter into polymer gels, Nature, 391, 568-572, 1998.

Cho, B. C. and Azam, F.: Major role of bacteria in biogeochemical fluxes in the oceans interior, Nature, 332, 441-443, 1988.

Copping, A. and Lorenzen, A. E.: Carbon budget of a marine phytoplankton-herbivore system with carbon-14 as a tracer, Limnol. Oceanogr., 25, 873-882, 1980.

Davis, J., Kaiser, K., and Benner, R.: Amino acid and amino sugar yields and compositions as indicators of dissolved organic matter diagenesis, Org. Geochem., 40, 343-352, 2009.

De Jong, E., van Rens, L., Westbroek, P., and Bosch, L.: Biocalcification by the marine alga Emiliania huxleyi (Lohmann) Kamptner, Europ. J. Biochem., 99, 559-567, 1979.

Del Giorgio, P. A. and Cole, J. J.: Bacterial growth efficiency in natural aquatic ecosystems, Annu. Rev. Ecol. Syst., 29, 503-541, 1998.

Engel, A.: Direct relationship between $\mathrm{CO}_{2}$ uptake and transparent exopolymer particles production in natural phytoplankton, J. Plankton Res., 24, 49-53, 2002.

Engel, A. and Händel, N.: A novel protocol for determining the concentration and composition of sugars in particulate and in high molecular weight dissolved organic matter (HMW-DOM) in seawater, Mar. Chem., 127, 180-191, 2011.

Engel, A., Thoms, S., Riebesell, U., Rochelle-Newall, E., and Zondervan, I.: Polysaccharide aggregation as a potential sink of marine dissolved organic carbon, Nature, 428, 929-932, 2004. 
Engel, A., Händel, N., Wohlers, J., Lunau, M., Grossart, H. P., and Sommer, U., and Riebesell, U.: Effects of sea surface warming on the production and composition of dissolved organic matter during phytoplankton blooms: results from a mesocosm study, J. Plankton Res., 33, 357-372, 2010.

Engel, A., Harlay, J., Piontek, J., und Chou, L.: Contribution of combined carbohydrates to dissolved and particulate organic carbon after the spring bloom in the northern Bay of Biscay (NorthEastern Atlantic Ocean), Contin. Shelf Res., 45, 42-53, 2012.

Engel, A., Borchard, C., Piontek, J., Schulz, K. G., Riebesell, U., and Bellerby, R.: $\mathrm{CO}_{2}$ increases ${ }^{14} \mathrm{C}$-primary production in an Arctic plankton community, Biogeosciences, 10, 1291-1308, doi:10.5194/bg-10-1291-2013, 2013.

Engel, A., Cisternas Novoa, C., Wurst, M., Endres, S., Tang, T., Schartau, M., and Lee, C.: No detectable effect of $\mathrm{CO}_{2}$ on elemental stoichiometry of Emiliania huxleyi in nutrient-limited, acclimated continuous cultures, Mar. Ecol.-Prog. Ser., 507, 1530, 2014.

Fichtinger Schepman, A. M. J., Kamerling, J. P., Vliegenthart, J. F. G., De Jong, E. W., Bosch, L., and Westbroek, P.: Composition of a methylated, acidic polysaccharide associated with coccoliths of Emiliania huxleyi (Lohmann) Kampner, Carbohyd. Res., 69, 181-189, 1979.

Flügge, U. I. and Benz, R.: Pore-forming activity in the outer membrane of the chloroplast envelope, FEBS Lett., 169, 85-89, 1984.

Flynn, K. Clark, D., and Xue, Y.: Modeling the release of dissolved organic matter by phytoplankton, J. Phycol., 44, 11711187, 2008.

Fogg, G. E.: The extracellular products of algae, Oceanogr. Mar. Biol., Annual Review, 4, 195-212, 1966.

Fogg, G. E.: The ecological significance of extracellular products of phytoplankton photosynthesis, Bot. Mar., 26, 3-14, 1983.

Fuhrman, J. A.: Marine viruses and their biogeochemical and ecological effects, Nature, 399, 541-548, 1999.

Gargas, E.: A Manual for Phytoplankton Primary Production Studies in the Baltic, Balt. Mar. Biolog., 2, 1-88, 1975.

Geider, R. J. and LaRoche, J.: Redfield revisited: variability of $\mathrm{C}: \mathrm{N}: \mathrm{P}$ in marine microalgae and its biochemical basis, Eur. J. Phycol., 37, 1-17, 2002.

Giroldo, D., Vieira, A. A. H., and Paulsen, B. S.: Extracellular polysaccharides produced by a tropical cryptophyte as a carbon source for natural bacterial populations, Eur. J. Phycol., 40, 241249, 2005.

Goldberg, S. J., Carlson, C. A., Bock, B., Nelson, N. B., and Siegel, D. A.: Meridional variability in dissolved organic matter stocks and diagenetic state within the euphotic and mesopelagic zone of the North Atlantic subtropical gyre, Mar. Chem., 119, 9-21, 2010.

Goldman, J. C., Hansell, D. A., and Dennett, M. R.: Chemical characterization of three large oceanic diatoms: Potential impact on water column chemistry, Mar. Ecol.-Prog. Ser., 88, 257-270, 1992.

Grasshoff, K., Kremeling, K., and Ehrhardt, M.: Methods of seawater analysis, Third, completely revised and extended edition, Wiley-VHC, 1999.

Guillard, R. R. L. and Ryther, J. H.: Studies of marine planktonic diatoms I, Cyclotella nana Hustedt and Detonula confervacea Cleve, Can. J. Microbiol., 8, 229-239, 1962.
Guo, L., Hung, C. C., Santschi, P. H., and Walsh, I. D.: ${ }^{234}$ Th scavenging and its relationship to acid polysaccharide abundance in the Gulf of Mexico, Mar. Chem. 78, 103-119, 2002.

Halewood, E. R., Carlson, C. A., Brzezinski, M. A., Reed, D. C., and Goodman J.: Annual cycle of organic matter partitioning and its availability to bacteria across the Santa Barbara Channel continental shelf, Aquat. Microb. Ecol., 67, 189-209, 2012.

Hansell, D. A.: Recalcitrant dissolved organic carbon fractions, Ann. Rev. Mar. Sci., 5, 421-445, 2013.

Hansell, D. A. and Carlson, C. A.: Deep ocean gradients in dissolved organic carbon gradients, Nature, 395, 263-266, 1998.

Hansell D. A., Carlson C. A., Repeta D. J., and Schlitzer R.: Dissolved organic matter in the ocean a controversy stimulates new insights, Oceanography, 22, 202-211, 2009.

Harlay, J., De Bodt, C., Engel, A., Jansen, S., d'Hoop, Q., Piontek, J., Van Oostende, N., Groom, S., Sabbe, K., und Chou, L.: Abundance and size distribution of transparent exopolymer particles (TEP) in a coccolithophorid bloom in the northern Bay of Biscay, Deep-Sea Res. Pt. I, 56, 1251-1265, 2009.

Hopkinson, C. S. and Vallino, J. J.: Efficient export of carbon to the deep ocean through dissolved organic matter, Nature, 433, 142145, 2005.

Jiao, N. and Zheng, Q.: The microbial carbon pump: from genes to ecosystems, Appl. Environ. Microbiol., 77, 7439-7444, 2011.

Kabisch, A., Otto, A., König, S., Becher, D., Albrecht, D., Schüler, M., Teeling, H., Amann, R. I., and Schweder, T.: Functional characterization of polysaccharide utilization loci in the marine Bacteroidetes 'Gramella forsetii' KT0803, The ISME Journal, 8, 1492-1502, 2014.

Kiørboe, T. and Hansen, J. L. S.: Phytoplankton aggregate formation: observation of patterns and mechanisms of cell sticking and the significance of exopolymeric material, J. Plankton Res., 15, 993-1018, 1993.

Kirchman, D. L.: Biomass and Production of Heterotrophic Bacterioplankton in the Oceanic Sub-Arctic Pacific, Deep-Sea Res. Pt. II, 40, 967-988, 1993.

LaRoche, J., Rost, B., and Engel, A.: Bioassays, batch culture and chemostat experimentation, Guide to best practices for ocean acidification research and data reporting, edited by: Riebesell U., Fabry V. J., Hansson L., and Gattuso J.-P., Luxembourg: Publications Office of the European Union, 81-94, 2010.

Leppard G. G.: The characterization of algal and microbial mucilages and their aggregates in aquatic ecosystems, Sci. Total Environ., 165, 103-131, 1995.

Lewis, E. and Wallace, D.: Program Developed for $\mathrm{CO}_{2}$ System Calculations. ORNL/CDIAC-105, Carbon Dioxide Information Analysis Center, Oak Ridge National Laboratory, US Department of Energy, Oak Ridge, Tennessee, 1998.

López-Sandoval, D., Marañón, E., Fernández, A., González, J., Gasol, J. M., Lekunberri, I., Varela, M., Calvo-Díaz, A., Morán, X. A., Álvarez- Salgado, X. A., and Figueiras, F. G.: Particulate and dissolved primary production by contrasting phytoplankton assemblages during mesocosm experiments in Ría de Vigo (NW Spain), J. Plankton Res., 32, 1231-1240, 2010.

López-Sandoval, D. C., Fernández, A., and Marañón, E.: Dissolved and particulate primary production along a longitudinal gradient in the Mediterranean Sea, Biogeosciences, 8, 815-825, doi:10.5194/bg-8-815-2011, 2011. 
Mague, T. H., Friberg, E., Hughes, D. J., and Morris, I.: Extracellular release of carbon by marine phytoplankton; a physiological approach, Limnol.Oceanogr., 25, 262-279, 1980.

Marañón E., Fernandez E., Harris R. P., and Harbour D. S.: Effects of the diatom-Emiliania huxleyi succession on photosynthesis, calcification and carbon metabolism by size-fractionated phytoplankton, Hydrobiologia, 317, 189-199, 1996.

Marañón, E., Cermeño, P., and Pérez, V.: Continuity in the photosynthetic production of dissolved organic carbon from eutrophic to oligotrophic waters, Mar. Ecol.- Prog. Ser., 299, 7-17, 2005

Mari, X. and Burd, A.: Seasonal size spectra of transparent exopolymeric particles (TEP) in a coastal sea and comparison with those predicted using coagulation theory, Mar. Ecol. Prog. Ser., 163, 63-76, 1998.

Mohr, H. and Schopfer, P.: Photosynthese als Funktion der Chloroplasten, In: Pflanzenphysiologie, Springer-Verlag Berlin Heidelberg New York, ISBN 3-540-54733-9, 139-172, 1992.

Møller, E. F.: Sloppy feeding in marine copepods: prey-sizedependent production of dissolved organic carbon, J. Plankton Res., 27, 27-35, 2005.

Moran, X. A. G., Sebastian, M., Pedros-Alio, C., and Estrada, M.: Response of Southern Ocean phytoplankton and bacterioplankton production to short-term experimental warming, Limnol. Oceanogr., 51, 1791-1800, 2006.

Myklestad, S.: Production of carbohydrates by marine planktonic diatoms I, Comparison of nine different species in culture, J. exp. mar. Biol. Ecol., 15, 261-274, 1974.

Myklestad, S., Haug, A., and Larsen, B.: Production of carbohydrates by the marine diatom Chaetoceros affinis var Willei (Gran) In Hustedt II: preliminary investigation of the extracellular polysaccharide, J. Exp. Mar. Biol. Ecol., 9, 137-144, 1972.

Myklestad, S., Holm-Hansen, O., Varum, K. M., and Volcani, B. E.: Rate of release of extracellular amino-acids and carbohydrates from the marine diatom Chaetoceros affinis, J. Plankton Res., 11, 763-773, 1989.

Nagata, T.: Production mechanisms of dissolved matter, in: Microbial Ecology of the Oceans, edited by: Kirchmann, D. L., 1st Edn., Wiley-Liss, New York, 121-152, 2000.

Nanninga, H. J., Ringenaldus, P., and Westbroek, P.: Immunological quantitation of a polysaccharide formed by Emiliania huxleyi, J. Marine Syst., 9, 67-74, 1996.

Obernosterer, I. and Herndl, G. J.: Phytoplankton extracellular release and bacterial growth: dependence on inorganic $\mathrm{N}: \mathrm{P}$ ratio, Mar. Ecol. Prog. Ser., 116, 247-257, 1995.

Ogawa, H. and Tanoue, E.: Dissolved organic matter in oceanic waters, J. Oceanogr., 59, 129-147, 2003.

Passow, U.: Formation of transparent exopolymer particles, TEP, from dissolved precursor material. Mar. Ecol.-Prog. Ser., 192, 111, 2000.

Passow, U.: Production of transparent exopolymer particles (TEP) by phyto- and Bacterioplankton, Mar. Ecol.-Prog. Ser., 236, 112, 2002.

Pakulski, J. D. and Benner, R.: Abundance and distribution of carbohydrates in the ocean, Limnol. Oceanogr., 39, 930-940, 1994.

Piontek, J., Lunau, M., Händel, N., Borchard, C., Wurst, M., and Engel, A.: Acidification increases microbial polysaccharide degradation in the ocean, Biogeosciences, 7, 1615-1624, doi:10.5194/bg-7-1615-2010, 2010.
Puddu, A., Zoppini, A., Fazi, S., Rosati, M., Amalfitano, S., and Magaletti, E.: Bacterial uptake of DOM released from P-limited phytoplankton, FEMS Microbiol. Ecol., 46, 257-268, 2003.

Repeta, D. J. and Aluwihare, L. I.: High molecular weight dissolved organic carbon cycling as determined by natural abundance radiocarbon measurements of neutral sugars, Limnol. Oceanogr., 51, 1045-1053, 2006.

Schartau, M., Engel, A., Schröter, J., Thoms, S., Völker, C., and Wolf-Gladrow, D.: Modelling carbon overconsumption and the formation of extracellular particulate organic carbon, Biogeosciences, 4, 433-454, doi:10.5194/bg-4-433-2007, 2007.

Sharp, J. H.: Excretion of organic matter by marine phytoplankton - Do healthy cells do it? Limnol. Oceanogr., 22, 381-399, 1977.

Skoog, A., Alldredge, A., Passow, U., Dunne, J., and Murray, J.: Neutral aldoses as source indicators for marine snow, Mar. Chem., 108, 195-206, 2008.

Smith, D. C., Simon, M., Alldredge, A. L., and Azam, F.: Intense hydrolytic enzyme-activity on marine aggregates and implications for rapid particle dissolution, Nature, 359, 139-142, 1992.

Smith, D. J. and Underwood G. J. C.: The production of extracellular carbohydrates by estuarine benthic diatoms: the effects of growth phase and light and dark treatment, J. Phycol., 36, 321333,2000

Staats, N., Stal, L. J., and Mura, L. R.: Exopolysaccharide production by the epipelic diatom Cylindrotheca closterium: effects of nutrient conditions, J. Exp. Mar. Biol. Ecol., 249, 13-27, 2000.

Steemann Nielsen, E.: The Use of Radioactive Carbon $\left({ }^{14} \mathrm{C}\right)$ for Measuring Primary Production in the Sea, J. Cons. Perm. Int. Explor. Mer., 18, 117-140, 1952.

Taylor, J. D., Ellis, R., Milazzo, M., Hall-Spencer, J. M., and Cunliffe, M.: Intertidal epilithic bacteria diversity changes along a naturally occurring carbon dioxide and $\mathrm{pH}$ gradient, FEMS Microbiol. Ecol., 89, 670-678, 2014.

Teeling, H., Fuchs, B. M., Becher, D., Klockow, C., Gardebrecht, A., Bennke, C. M., Kassabgy, M., Huang, S., Mann, A. J., Waldmann, J., Weber, M., Klindworth, A., Otto, A., Lange, J., Bernhardt, J., Reinsch, C., Hecker, M., Peplies, J., Bockelmann, F. D. , Callies, U., Gerdts, G., Wichels, A., Wiltshire, K. H., Glöckner, F. O., Schweder, T., and Amann, R.: Substrate-controlled succession of marine bacterioplankton populations induced by a phytoplankton bloom, Science, 336, 608-611, 2012.

Thornton, D. C. O.: Effect of low $\mathrm{pH}$ on carbohydrate production by a marine planktonic diatom (Chaetoceros muelleri), Res. Lett. Ecol., ID 105901, 2009.

Wangersky, P. J.: The Distribution of Particulate Organic Carbon in the Oceans: Ecological Implications, Internationale Revue der gesamten Hydrobiologie und Hydrographie, 63, 567-574, 1978.

Wetz, M. S. and Wheeler, P. A.: Release of organic matter by coastal diatoms, Limnol. Oceanogr., 52, 798-807, 2007.

Williams P. J. L. B.: The importance of losses during microbial growth: commentary on the physiology, measurement and ecology on the release of dissolved organic matter, Mar. Microb. Food Webs, 4, 175-206, 1990.

Wood, M. A. and van Valen, L. M.:Paradox lost?, On the release of energy-rich compounds by phytoplankton, Mar. Microb. Food Webs, 4, 103-116, 1990.

Zlotnik, I. and Dubinsky, Z.: The effect of light and temperature on DOC excretion by phytoplankton, Limnol. Oceanogr., 34, 831839, 1989. 